EXPERIMENTAL STUDY

\title{
Differential expression of somatostatin receptor subtypes in human peripheral blood mononuclear cell subsets
}

\author{
Elgin G R Lichtenauer-Kaligis ${ }^{1}$, Virgil A S H Dalm ${ }^{1}$, Sigrid P M A Oomen ${ }^{2}$, Diana M Mooij ${ }^{1}$, \\ $\mathrm{P}$ Martin van Hagen ${ }^{1,3}$, Steven W J Lamberts ${ }^{1}$ and Leo J Hofland ${ }^{1}$ \\ Departments of ${ }^{1}$ Internal Medicine, ${ }^{2}$ Haematology and ${ }^{3}$ Immunology, Erasmus MC, Rotterdam, The Netherlands \\ (Correspondence should be addressed to L J Hofland, Department of Internal Medicine, Room Bd 240, Erasmus MC, Dr Molewaterplein 40, 3015 GD \\ Rotterdam, The Netherlands; Email: l.hofland@erasmusmc.nl)
}

(E G R Lichtenauer-Kaligis and VA S H Dalm contributed equally to this work)

\begin{abstract}
Background: Somatostatin (SS)-binding sites have been demonstrated in human lymphoid tissues and peripheral blood cells. However, not much is known with respect to the SS receptor subtype (sst) expression pattern and the expression of SS itself in the immune system.

Objective: The aim of this study was to evaluate the mRNA expression of the five known sst $\left(\mathrm{sst}_{1-5}\right)$ in peripheral blood mononuclear cell (sub)populations. Moreover, the expression of the mRNAs encoding SS and the SS-like peptide cortistatin (CST) in immune cell subsets was studied.

Methods: RT-PCR and quantitative PCR were performed to evaluate sst, SS and CST mRNA expression in cells in the basal or activated state. Fluorescence-activated cell sorter (FACS) analysis using fluorescent SS was performed to visualize sst protein on cell membranes.

Results: B- and T-lymphocytes selectively expressed sst $_{3}$ mRNA. $_{\text {sst }}{ }_{3}$ expression in B-lymphocytes was significantly lower compared with T-lymphocytes. Unstimulated, freshly isolated monocytes did not

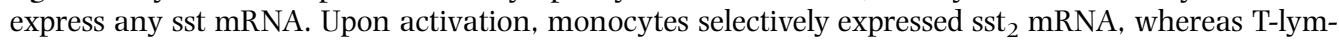
phocyte activation upregulated sst $_{3}$ expression. sst $_{2}$ mRNA expression on monocytes was confirmed by FACS analysis. B- and T-lymphocytes did not express SS mRNA, while both cell types expressed CST mRNA. CST mRNA expression was downregulated following T-lymphocyte activation.

Conclusion: We demonstrate for the first time unequivocally that human peripheral blood B- and T-lymphocytes selectively express $\mathrm{sst}_{3}$, whereas monocytes do not express sst. However, upon activation, monocytes are induced to express $\mathrm{sst}_{2 \mathrm{~A}}$. No expression of SS mRNA was detected in any cell type, whereas all cell types expressed CST mRNA. The differential expression of sst and CST mRNA in lymphocytes and monocytes suggests a functional significance for the CST-sst interaction in immune cells, but further studies should be performed to evaluate the significance of sst and CST in these cells.
\end{abstract}

European Journal of Endocrinology 150 565-577

\section{Introduction}

Somatostatin (SS) is a small neuropeptide that is widely distributed throughout the body and has numerous functions. In the endocrine system it was originally characterized as an inhibitor of growth hormone secretion by the pituitary (1). SS also inhibits hormone secretion from the gastrointestinal tract $(2,3)$, whereas in the nervous system it functions as a neurotransmitter (4). A growing body of evidence suggests a role for SS in the immune system as well $(5,6)$. SS acts on its target cells through specific G-protein coupled transmembrane receptors. Initially, these receptors were identified as binding sites for radiolabelled ligands (7), usually SS or the more stable synthetic analogue octreotide. Later on, the genes of five different subtypes were isolated. These SS receptor subtypes (sst) are being characterized with respect to binding affinities for SS analogues, coupling to effector systems for signal transduction and tissue distribution of mRNA expression (8).

Although there are numerous studies demonstrating the presence of SS-binding sites or effects of SS in lymphoid tissues, immune cells or lymphoid cell lines, the data obtained so far do not present a clear view of the function of SS in the immune system. A first step towards understanding should be the elucidation of the expression patterns of SS and its sst in the immune system. In situ autoradiography and in vivo scintigraphy have repeatedly demonstrated the presence of SS-binding sites in human lymphoid tissues (9-16); however, it is not yet evident which sst are expressed. It is also not clear how receptor expression is regulated in the immune tissues and in immune cells in the peripheral blood. 
Reports in the literature on this issue have been quite equivocal. SS-binding sites in peripheral blood mononuclear cells (PBMCs) were described by Bathena et al. (17) in 1981. However, Hiruma et al. (18) were unable to detect SS-binding sites on resting PBMCs; only after mitogen activation were such binding sites detected. Similarly, mRNA for sst subtype $2\left(\mathrm{sst}_{2}\right)$ could barely be detected in unstimulated human PBMCs, but was readily detected after mitogen stimulation (19). In contrast, sst $_{5}$ was reported to be responsible for growth inhibition of PMBCs by SS analogues (20). Additionally, several human lymphoid cell lines were shown to bear SS-binding sites (21). Such cell lines can also express mRNA for several sst $(19,22)$ and functionally respond to SS or SS analogues (22-24). These data, however, yield by no means a conclusive notion of the expression pattern of sst in human immune cells in vivo. Comparison with data obtained on PBMCs and other lymphoid tissues from rat (25) or mouse (26) demonstrate species-related differences and add to the confusion as to which sst are expressed in human immune cells.

Therefore, in the present study we set out to clarify the issue whether or not human PBMC subsets in the circulation express sst and their natural ligand SS. Moreover, we investigated the expression of the mRNA encoding a recently discovered SS-like peptide, cortistatin (CST), which we previously found to be widely expressed in cells and tissues from the human immune system (27). CST shows high structural resemblance to SS (28) and binds with high affinity to all five sst (29). Accordingly, we isolated human PBMCs and determined by RT-PCR whether SS, CST or sst were expressed, and whether the expression pattern is altered by mitogen activation. Moreover, we separated the human PBMC cell fraction into subpopulations and determined the expression patterns in T-lymphocytes, B-lymphocytes and monocytes. By quantitative PCR (Q-PCR) we subsequently studied the regulation of the sst and CST mRNA expression in PBMCs and monocytes. To gain more insight into the cell-typespecific expression of SS and its receptors in the human immune system, a comparison was made with the expression levels of sst in several other cell lines and primary human immune cell types.

\section{Materials and methods}

\section{Cells, media and reagents}

PBMCs were isolated from $20-40 \mathrm{ml}$ blood from eight different healthy donors using Ficoll density-gradient separation immediately after blood withdrawal. After Ficoll separation, PBMCs were kept on ice to prevent changes in mRNA expression during further treatment of the cells. PBMCs or isolated subpopulations were either used directly for mRNA analysis or cultured for $24 \mathrm{~h}$ at $37^{\circ} \mathrm{C}$ in a $5 \% \quad \mathrm{CO}_{2}$ incubator in RPMI medium supplemented with $10 \%$ heat-inactivated fetal calf serum (Life Technologies), $10^{5} \mathrm{U} / \mathrm{l}$ penicillin and $1.25 \mathrm{mg} / \mathrm{l}$ Fungizone. PBMCs of three different donors were used for further culture. As mitogenic stimuli, we added either $2 \mu \mathrm{g} / \mathrm{ml}$ phytohaemagglutinin (PHA), $3 \mu \mathrm{g} / \mathrm{ml}$ concanavalin A (ConA), $1 \mu \mathrm{g} / \mathrm{ml}$ lipopolysaccharide (LPS) or $10 \mu \mathrm{g} / \mathrm{ml}$ pokeweed mitogen (PWM). After $24 \mathrm{~h}$ the cultured cells were harvested for mRNA isolation as described below.

For fluorescent ligand-binding experiments (see below) cell populations enriched for lymphocytes or monocytes were used. Enrichment for lymphocytes was achieved by allowing the monocytes among the PBMCs to adhere to culture dishes and subsequently collecting the non-adherent lymphocyte fraction for further culturing. Monocytes were isolated by performing a Percoll density gradient following a standard Ficoll density gradient as described previously (30).

\section{Separation of PBMCs into subpopulations}

Subpopulations of PBMCs were isolated by means of magnetic beads coated with specific antibodies (Dynal AS, Oslo, Norway). For T-lymphocyte isolation, beads coated with CD2 or CD3 antibody were used, while CD19-antibody-coated and CD14-antibody-coated beads were used for B-lymphocyte and monocyte isolation respectively. To distinguish between T-helper cells and cytotoxic T-cells, beads coated with respectively CD4 or CD8 antibodies were used. Isolation of cells was performed following the manufacturer's instructions. After separation procedures, cells were either used for RT-PCR or cultured for $24 \mathrm{~h}$ as described above.

\section{RT-PCR}

RT-PCR was performed as described previously (31). Briefly, poly $\mathrm{A}^{+}$mRNA was isolated using Dynabeads Oligo $(\mathrm{dT})_{25}$ (Dynal) from cell samples. cDNA was synthesized using the poly $\mathrm{A}^{+}$mRNA, which was eluted from the beads in $40 \mu \mathrm{l} \mathrm{H}_{2} \mathrm{O}$ for $10 \mathrm{~min}$ at $65^{\circ} \mathrm{C}$, using Oligo $(\mathrm{dT})_{12-18}$ Primer (Life Technologies). One-twentieth of the cDNA library was used for each amplification by PCR using primer sets specific for human SS, sst $_{1-5}$, CST and hypoxanthine phosphoribosyl transferase (hprt) (see Table 1A) as a control. As positive controls for SS, CST and hprt, cDNA of human brain RNA (Invitrogen, Groningen, The Netherlands) was used. As positive control for $\mathrm{sst}_{1-5}$, DNA of a BLCL-BSM cell line (an EBV-transformed B-cell line) was used. The PCR reaction was carried out in a DNA thermal cycler with a heated lid (Applied Biosystems, Nieuwerkerk aan de Ijssel, The Netherlands). After an initial denaturation at $94{ }^{\circ} \mathrm{C}$ for $5 \mathrm{~min}$, the samples were subjected to 40 cycles of denaturation at $94^{\circ} \mathrm{C}$ for $1 \mathrm{~min}$, annealing for $2 \mathrm{~min}$ at $60^{\circ} \mathrm{C}$ and extension for $1 \mathrm{~min}$ at $72^{\circ} \mathrm{C}$. After a final extension for $10 \mathrm{~min}$ at $72{ }^{\circ} \mathrm{C}, 10 \mu \mathrm{l}$ aliquots of the resulting PCR products were analysed by electrophoresis on $1.5 \%$ agarose gels stained with 


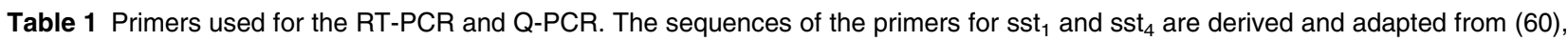
for sst $_{5}$ from (61), for CST from (62) and all other primers and probes were designed by use of the Primer3! software (http:// www-genome.wi.mit.edu/genome_software/other/primer3. html) and the appropriate GenBank entries.

\begin{tabular}{|c|c|c|}
\hline & Sequence $\left(5^{\prime}-3^{\prime}\right)^{a}$ & PCR product $(b p)$ \\
\hline \multicolumn{3}{|l|}{ A. RT-PCR } \\
\hline sst $_{1}$ (forward) & ATGGTGGCCCTCAAGGCCGG & \multirow[t]{2}{*}{318} \\
\hline sst $_{1}$ (reverse) & CGCGGTGGCGTAATAGTCAA & \\
\hline $\mathrm{sst}_{2 \mathrm{~A}}\left(\right.$ forward $^{\mathrm{b}}$ & GCCAAGATGAAGACCATCAC & \multirow[t]{2}{*}{414} \\
\hline sst $_{2 \mathrm{~A}}$ (reverse) & GATGAACCCTGTGTACCAAGC & \\
\hline $\mathrm{sst}_{3}$ (forward) & CCAACGTCTACATCCTCAACC & \multirow[t]{2}{*}{314} \\
\hline $\mathrm{sst}_{3}$ (reverse) & TCCCGAGAAGACCACCAC & \\
\hline $\mathrm{sst}_{4}$ (forward) & ATCTTCGCAGACACCAGACC & \multirow[t]{2}{*}{321} \\
\hline sst $_{4}$ (reverse) & ATCAAGGCTGGTCACGACGA & \\
\hline sst $_{5}$ (forward) & CGTCTTCATCATCTACACGG & \multirow[t]{2}{*}{226} \\
\hline sst $_{5}$ (reverse) & CCGTCTTCATCATCTACACGG & \\
\hline Somatostatin (forward) & GATGCTGTCCTGCCGCCTCCAG & \multirow[t]{2}{*}{349} \\
\hline Somatostatin (reverse) & ACAGGATGTGAAAGTCTTCCA & \\
\hline CST (forward) & GCAAATTCGCTCTAAACACAGGA & \multirow[t]{2}{*}{173} \\
\hline CST (reverse) & TTGGGAAGGAGGAGAGGAAAGAT & \\
\hline hprt (forward) & CAGGACTGAACGTCTTGCTC & \multirow[t]{2}{*}{413} \\
\hline hprt (reverse) & CAAATCCAACAAAGTCTGGC & \\
\hline \multicolumn{3}{|l|}{ B. Q-PCR } \\
\hline sst $_{2 \mathrm{~A}}$ (forward) & ATGCCAAGATGAAGACCATCAC & \multirow[t]{3}{*}{171} \\
\hline sst $_{2 \mathrm{~A}}$ (reverse) & TGAACTGATTGATGCCATCCA & \\
\hline sst $_{2 A}$ (probe) & TGGCTCTGGTCCACTGGCCCTTTG & \\
\hline $\mathrm{sst}_{3}$ (forward) & CTGGGTAACTCGCTGGTCATCTA & \multirow[t]{3}{*}{86} \\
\hline $\mathrm{sst}_{3}$ (reverse) & AGCGCCAGGTTGAGGATGTA & \\
\hline $\mathrm{sst}_{3}$ (probe) & CGGCCAGCCCTTCAGTCACCAAC & \\
\hline CST (forward) & GGAGAGAAGCTCCAGTCAGC & \multirow[t]{3}{*}{198} \\
\hline CST (reverse) & GGTCCACTCAAACCACCAA & \\
\hline CST (probe) & TATGCTCGCTGTCTCGGCCG & \\
\hline hprt (forward) & TGCTTTCCTTGGTCAGGCAGTAT & \multirow[t]{3}{*}{109} \\
\hline hprt (reverse) & TCAAATCCAACAAAGTCTGGCTTATATC & \\
\hline hprt (probe) & CAAGCTTGCGACCTTGACCATCTTTGGA & \\
\hline
\end{tabular}

a The position is given of the $5^{\prime}$ nucleotide of the primer relative to the first nucleotide of the coding region in the cDNA sequence.

${ }^{b}$ The $s t_{2}$ primers are specific for $s_{2} t_{2 A}$. In initial experiments we also included primers that amplify both sst ${ }_{2 A}$ and $s s t_{2 B}$, but the sst ${ }_{2 B} s p e c i f i c$ product was never found (unpublished results)

ethidium bromide. The identity of the products was confirmed by direct sequencing using an ABI Prism 3100 Genetic Analyser (Applied Biosystems) according to the manufacturer's protocol (data not shown). Several controls were included in the RT-PCR experiments. To ascertain that no detectable genomic DNA was present in the polyA ${ }^{+}$mRNA preparation (since the sst genes are intron-less), the cDNA reactions were also performed without reverse transcriptase (RT) and amplified with each primer pair. Amplification of the cDNA samples with the hprt-specific primers served as positive control for the quality of the cDNA. To exclude contamination of the PCR reaction mixtures, the reactions were also performed in the absence of the DNA template in parallel with cDNA samples. No PCR products were formed in the samples without RT or in the absence of cDNA template (not shown). As a positive control for the PCR reactions of the sst receptor subtypes, $0.1-0.001 \mu \mathrm{g}$ human genomic DNA, representing approximately 30000 to 300 copies of sst template, was amplified in parallel with the cDNA samples. As a positive control for the PCR of the hprt, SS and CST cDNA, aliquots of a cDNA sample known to contain SS, CST and hprt mRNA were amplified, because these primer pairs did enclose introns in the genomic DNA.

\section{Q-PCR}

Q-PCR was performed employing a nuclease assay (32) for real-time detection of amplification $(33,34)$ with an ABI Prism 7700 Sequence Detection System (i.e. thermal cycler and real-time fluorescence detector; Perkin Elmer, Nieuwerkerk aan de Ijssel, The Netherlands). New primer sets were designed for use in quantitative PCR of sst $_{2 \mathrm{~A}}, \mathrm{sst}_{3}$, hprt and CST with accompanying probes for the detection of the PCR products (Table 1B). These were obtained from BioSource (Nivelles, Belgium).

In each experiment, standard curves for each primer set were included. Known amounts of genomic DNA containing $\mathrm{sst}_{2 \mathrm{~A}}$ and $\mathrm{sst}_{3}$ or dilutions of a pool of hprt or CST containing cDNAs were amplified (in duplicate or triplicate) together with the unknown cDNA samples. A standard curve was constructed by plotting the $\mathrm{Ct}$ vs the logarithm of the starting quantity. With these standard curves and the measured $\mathrm{Ct}$ of the unknown cDNA samples the starting amounts in the cDNA 
samples were determined in duplicate or triplicate. To correct for differences in the efficiency of RNA isolation and cDNA synthesis the amounts of $\mathrm{sst}_{2 \mathrm{~A}}, \mathrm{sst}_{3}$ and CST were divided by the amount of hprt in a given cDNA sample. Since the absolute copy number of hprt templates in the control cDNAs used for the hprt standard curve is not known, the starting amounts are given in arbitrary units.

\section{Fluorescent SS binding}

To detect SS-binding sites on PBMCs the fluoresceinlabelled SS analogue fluosomatostatin (Fluo-SS) (Advanced Bioconcept, Montreal, Canada) was used. Cells were washed with PBS containing 0.5\% BSA and incubated at room temperature with $50 \mathrm{nmol} / \mathrm{l}$ Fluo-SS or with $50 \mathrm{nmol} / \mathrm{l}$ Fluo-SS and $5000 \mathrm{nmol} / \mathrm{l}$ D-trp ${ }^{8}$-SS14. After $30 \mathrm{~min}$ incubation an appropriate dilution of phycoerythrin (PE)-labelled CD3, CD19 (Becton Dickinson, Erembodegem, Belgium) or CD14 antibodies (Beckman Coulter, Mijdrecht, The Netherlands) was added. Following a further $15 \mathrm{~min}$ incubation the cells were washed, resuspended in PBS containing $0.5 \% \mathrm{BSA}$ and $20 \mathrm{mmol} / \mathrm{l}$ sodium azide and analysed on a fluorescence-activated cell sorter (FACS) (FACScan Cytometer; Becton Dickinson). As a positive control for ligand binding, a cell line stably transfected with $\mathrm{sst}_{2 \mathrm{~A}}$ was used.

\section{Results}

\section{sst, SS and CST mRNA in PBMCs}

To determine whether or not sst mRNA is expressed in the PBMC cell fraction of circulating blood we started isolation of the cells immediately after blood withdrawal and were able to lyse the cells within $2 \mathrm{~h}$. This guarantees that the RNA expression pattern of the studied cells resembles that of the live cells in the circulation as closely as possible. In doing so, we consistently found expression of $\mathrm{sst}_{3}$ mRNA in all eight PBMC samples by RT-PCR (Fig. 1). In some experiments a very weak sst $_{2 \mathrm{~A}}$ PCR product could be detected as well, but only after 40 cycles when the detection limit for $\mathrm{sst}_{2 \mathrm{~A}}$ was better than $1 \%$ of the population. None of the other sst subtypes could be detected, nor mRNA for SS itself (Table 2). However, we detected the mRNA for CST in all cell samples (Table 2). In some experiments also a PCR specific for $\mathrm{sst}_{2 \mathrm{~B}}$ was performed, but this subtype was never detected (results not shown).

After culturing the eight isolated PBMC preparations for $24 \mathrm{~h}$ in medium alone or in medium containing the mitogenic agents PHA, ConA, PWM or LPS the expression of $\mathrm{sst}_{2 \mathrm{~A}}$ mRNA was clearly induced (Fig. 1; Table 2). The expression pattern of the other sst and of SS remained unchanged $\left(\mathrm{sst}_{3}\right.$ detectable, others not, no SS).

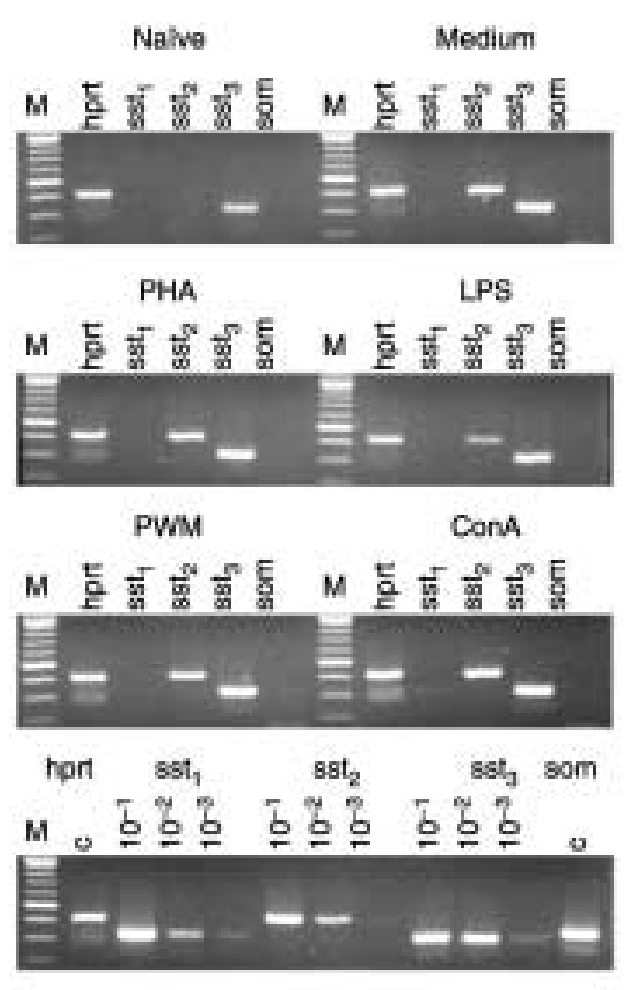

Figure 1 RT-PCR analysis of SS (som) and SS receptor expression in naïve and cultured PBMCs. PBMCs were assayed for expression of mRNA immediately after isolation (naïve) or after $24 \mathrm{~h}$ culturing in culture medium alone (medium) or with the addition of PHA, LPS, PWM or ConA. Control DNA samples contained either cDNA (lanes $c$ ) from a control cell line known to express hprt and SS mRNA, or different amounts of genomic DNA (lanes $10^{-1}, 10^{-2}$ and $10^{-3} \mu \mathrm{g}$ ) comprising 30000,3000 and 300 copies of sst genes respectively. All mock-reverse-transcribed samples and all controls with no added template showed no PCR products and none of the samples expressed sst $_{4}$ or sst $_{5}$ (not shown). Marker lanes (M) contain a 100 bp DNA ladder. This Figure shows mRNA expression of one healthy donor as representative of the eight donors used.

\section{Expression in T-Iymphocytes, B-Iymphocytes and monocytes}

To determine in which cell-type $\mathrm{sst}_{2 \mathrm{~A}}$ and $\mathrm{sst}_{3}$ receptors are expressed, we separated the PBMC cell population into its main subpopulations of T-lymphocytes, B-lymphocytes and monocytes by use of paramagnetic beads coated with appropriate antibody. The isolated cell populations were subsequently assayed by RT-PCR (Fig. 2; Table 2). The results demonstrated that $\mathrm{sst}_{3}$ was expressed by $\mathrm{CD} 3^{+}$T-lymphocytes and by $\mathrm{CD} 19^{+}$ B-lymphocytes, but not by $\mathrm{CD} 14^{+}$monocytes. None of the other sst or SS was expressed in these three subpopulations, whereas the expression of CST mRNA was found in all subpopulations evaluated (Table 2). Isolation of T-lymphocytes by CD2-antibody-coated instead of CD3-antibody-coated beads yielded similar results. Culturing the isolated cell populations during 
Table 2 Expression of somatostatin receptor subtype, CST and SS mRNA in PBMCs $(n=8)$, purified peripheral blood Tlymphocytes $(n=4)$, B-lymphocytes $(n=4)$ and monocytes $(n=4)$.

\begin{tabular}{|c|c|c|c|c|c|c|c|}
\hline & sst $_{1}$ & sst $_{2 A}$ & sst $_{3}$ & sst $_{4}$ & sst $_{5}$ & CST & SS \\
\hline \multicolumn{8}{|l|}{ PBMCs } \\
\hline $\mathrm{Oh}$ & - & - & + & - & - & + & - \\
\hline $24 \mathrm{~h}$ medium & - & + & + & - & - & + & - \\
\hline $24 \mathrm{~h}$ PHA & - & + & + & - & - & + & - \\
\hline 24 h ConA & - & + & + & - & - & ni & - \\
\hline $24 \mathrm{~h}$ PWM & - & + & + & - & - & ni & - \\
\hline $24 \mathrm{~h}$ LPS & - & + & + & - & - & ni & - \\
\hline \multicolumn{8}{|c|}{ T-lymphocytes $\left(\mathrm{CD3}^{+}\right)$} \\
\hline $\mathrm{Oh}$ & - & - & + & - & - & + & - \\
\hline $24 \mathrm{~h}$ medium & - & - & + & - & - & + & - \\
\hline 24 h ConA & - & - & + & - & - & + & - \\
\hline \multicolumn{8}{|c|}{ B-lymphocytes $\left(\mathrm{CD} 19^{+}\right)$} \\
\hline $\mathrm{Oh}$ & - & - & + & - & - & + & - \\
\hline $24 \mathrm{~h}$ medium & - & - & + & - & - & + & - \\
\hline $24 \mathrm{~h}$ PWM & - & - & + & - & - & + & - \\
\hline \multicolumn{8}{|c|}{ Monocytes (CD14 $\left.{ }^{+}\right)$} \\
\hline $\mathrm{Oh}$ & - & - & - & - & - & + & - \\
\hline $24 \mathrm{~h}$ medium & - & + & - & - & - & + & - \\
\hline $24 \mathrm{~h}$ LPS & - & + & - & - & - & + & - \\
\hline
\end{tabular}

ni $=$ not investigated.

$24 \mathrm{~h}$ in medium alone or in medium containing ConA, PWM or LPS induced $\mathrm{sst}_{2 \mathrm{~A}}$ in the monocyte fraction only (Fig. 2). sst $_{3}$ expression remained confined to Tand B-lymphocytes, whereas the other sst and SS were still undetected in all cell populations studied (Fig. 2; Table 2). In the same way we determined the expression pattern of unstimulated and ConA-stimulated $\mathrm{CD}^{+}{ }^{+}$and $\mathrm{CD} 8^{+}$T-lymphocytes and found in all populations a selective expression of $\mathrm{sst}_{3} \mathrm{mRNA}$ (data not shown).

\section{Quantification of sst $_{2 A}$, sst $_{3}$ and CST mRNA expression}

To quantify the induction of $\mathrm{sst}_{2 \mathrm{~A}}$ mRNA after activation we performed a Q-PCR on cDNA of PBMCs from four donors and on purified monocytes from two donors before and after activation $(24 \mathrm{~h}$ culturing in medium). The $\mathrm{sst}_{2 \mathrm{~A}}$ and $\mathrm{sst}_{3} \mathrm{mRNA}$ expression (in arbitrary units) corrected for the amount of hprt in the different samples is shown in Fig. 3. In all PBMC samples there was a significant induction of $\mathrm{sst}_{2 \mathrm{~A}}$ mRNA levels after activation. In the monocyte populations purified from two of the donors the induction was even larger. In three of the four donors also the $\mathrm{sst}_{3}$ expression in PBMCs was slightly increased after activation. Among the donors the expression levels of both $\mathrm{sst}_{2 \mathrm{~A}}$ (after activation) and $\mathrm{sst}_{3}$ showed a broad range.

Since the very low amount of $\mathrm{sst}_{2 \mathrm{~A}}$ mRNA in naïve cells cannot be determined with the same accuracy as the higher copy numbers, it is difficult to express the induction as a fold of the level in naïve cells. However, the $\mathrm{sst}_{2 \mathrm{~A}}$ copy number obtained after RNA isolation and cDNA synthesis per million PBMCs increased from approximately 1000 (or less) to $25000-$ 150000 . In contrast, the number of sst3 copies obtained per million naïve PBMCs was approximately 7000-15000. From three donors of PBMCs, T- and B-lymphocytes were isolated and Q-PCR was performed to quantify the expression of $\mathrm{sst}_{2 \mathrm{~A}}, \mathrm{sst}_{3}$ and CST mRNA in these cell subsets as well.

As already demonstrated by RT-PCR, T- and B-lymphocytes were found to express $\mathrm{sst}_{3}$ selectively. After $24 \mathrm{~h}$ of culture, expression of $\mathrm{sst}_{3}$ mRNA was upregulated approximately 1.5-fold in T-lymphocytes. After a $24 \mathrm{~h}$ incubation with PHA, sst 3 mRNA levels were upregulated approximately 2.5-fold when compared with control cells (Fig. 4). In B-lymphocytes, on the other hand, we were not able to detect expression of sst $_{3}$ mRNA by Q-PCR, even after culture and stimulation with PHA (data not shown). This is probably due to very low expression levels of $\mathrm{sst}_{3}$ in B-lymphocytes and probably the conditions or primers for RT-PCR are more sensitive to detect these low levels.

For comparison we determined the expression levels of $\mathrm{sst}_{2 \mathrm{~A}}$ and $\mathrm{sst}_{3}$ in several other normal human

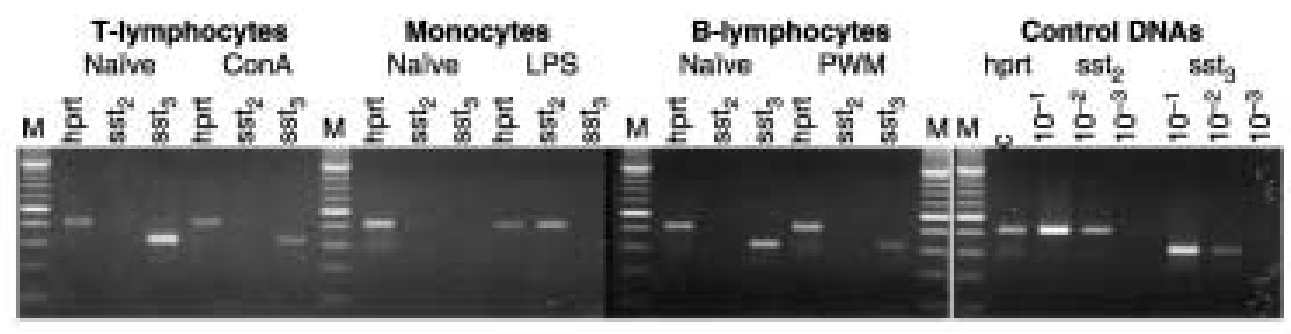

Figure 2 RT-PCR analysis of $\mathrm{sst}_{2}$ and $\mathrm{sst}_{3}$ expression in naïve and cultured purified T-lymphocytes, monocytes and B-lymphocytes. Cells were assayed for expression of mRNA immediately after isolation (naïve) or after $24 \mathrm{~h}$ culturing in culture medium with the addition of ConA, LPS or PWM. Control DNA samples contained either cDNA from a control cell line (lane c) or different amounts of genomic DNA (lanes $10^{-1}, 10^{-2}$ and $10^{-3} \mu \mathrm{g}$ ) comprising 30000,3000 and 300 copies of sst genes respectively. All mock-reverse-transcribed samples and all controls with no added template showed no PCR products and none of the samples expressed sst ${ }_{1}$, sst s $_{4}$ or sst $_{5}$ (not shown). Marker lanes (M) contain a 100 bp DNA ladder. Results represent an example of the findings in cell separations from four individual healthy donors. 
PBMC
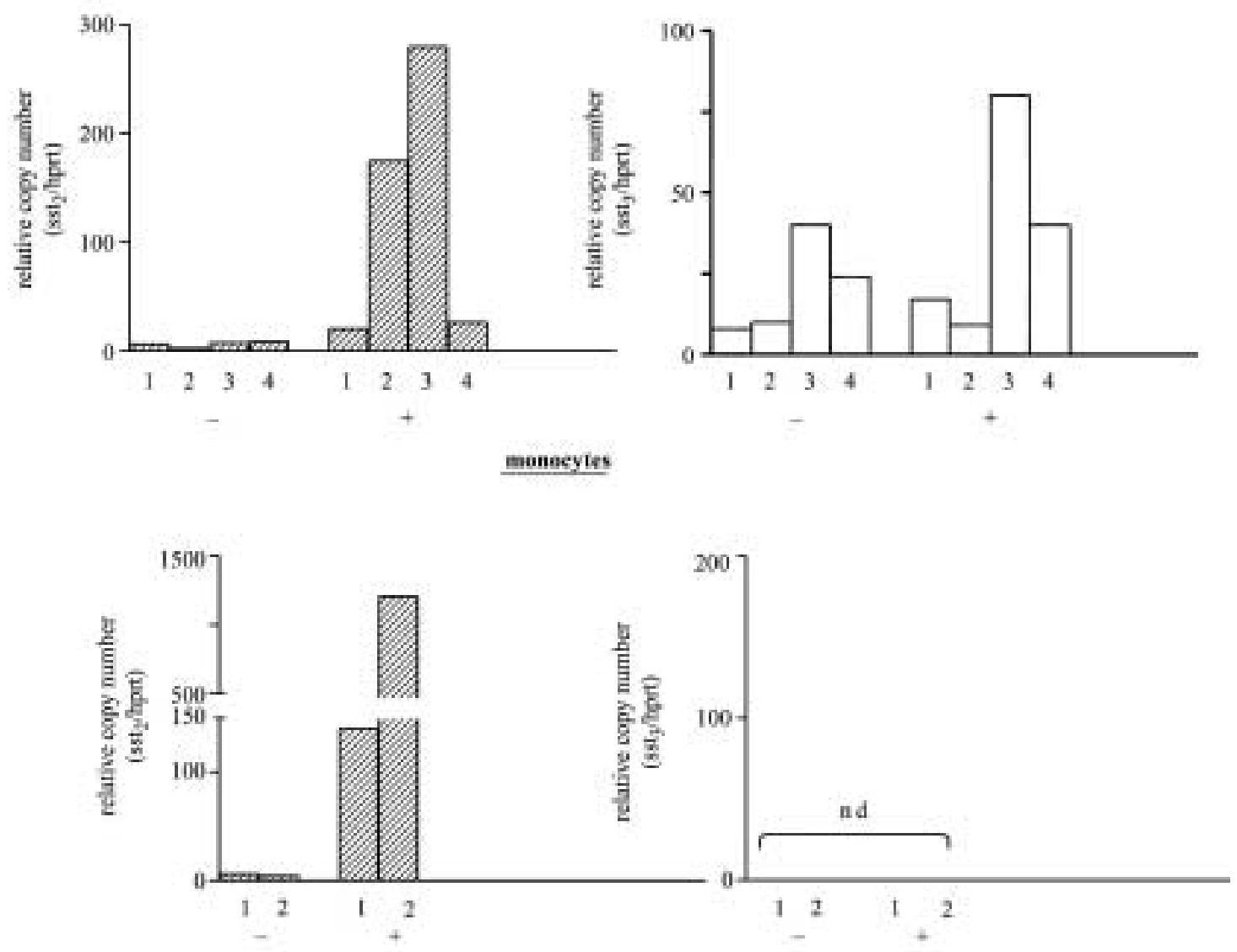

T-1ymphocgtes
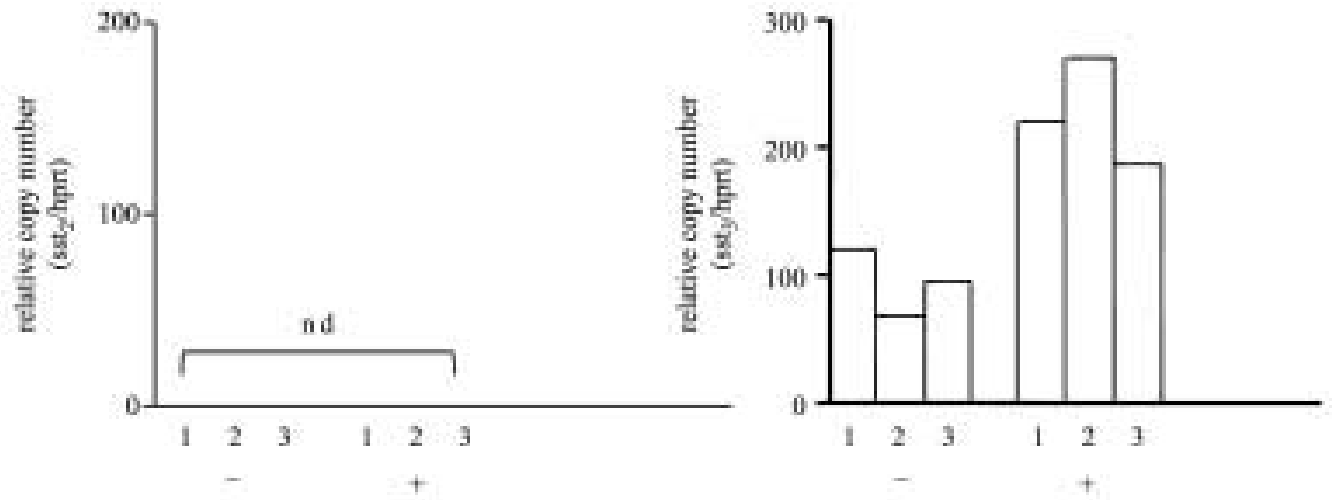

Figure 3 Quantitative PCR analysis of $\mathrm{sst}_{2 \mathrm{~A}}$ and $\mathrm{sst}_{3} \mathrm{mRNA}$ expression in human immune cells. $\mathrm{sst}_{2 \mathrm{~A}}$ and $\mathrm{sst}_{3}$ levels were corrected for the amount of hprt detected in each sample and are given in arbitrary units. PBMCs from four donors, monocytes from two donors and T- lymphocytes from three donors were analysed in naïve $(-)$ and activated $(+)$ states. Hatched bars represent $s_{2 A}$ mRNA, white $_{2 A}$ bars represent $\mathrm{sst}_{3}$ mRNA. nd $=$ not detected.

immune cells, in leukaemic cells and in lymphoid cell lines (Fig. 5). In freshly dispersed normal human thymocytes the $\mathrm{sst}_{3}$ expression levels were similar to the levels found in PBMCs, whereas there was more $\mathrm{sst}_{2 \mathrm{~A}}$ mRNA than in naïve PBMCs. In normal human bone marrow cells, the expression of $\mathrm{sst}_{2 \mathrm{~A}}$ was much higher. Although the expression level of $\mathrm{sst}_{2 \mathrm{~A}}$ in human haematological tumour cells is highly variable, $\mathrm{sst}_{2 \mathrm{~A}}$ was present in both tumour cell populations studied. sst $_{3}$ was just detectable in normal bone marrow 


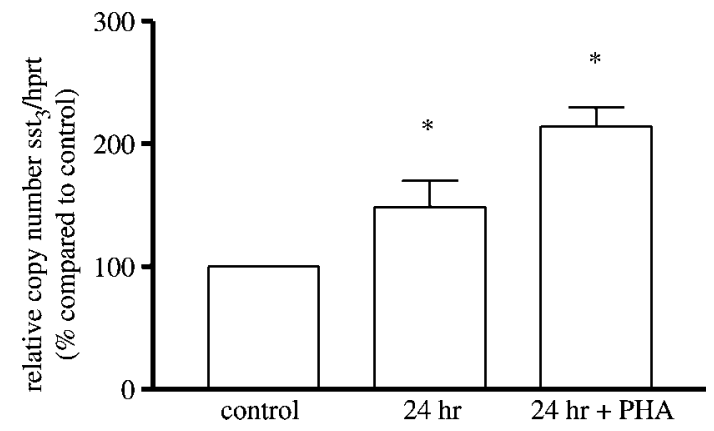

Figure 4 Expression of $s t_{3}$ mRNA in T-lymphocytes. This figure represents the expression of $s_{3}{ }_{3}$ mRNA in T-lymphocytes. sst $_{3}$ mRNA levels were corrected for hprt levels and bars represent the percentage of upregulation compared with control cells. Expression levels of $\mathrm{sst}_{3}$ mRNA were evaluated in freshly isolated T-lymphocytes (control), in T-lymphocytes after $24 \mathrm{~h}$ of culture $(24 \mathrm{hr}$ ) and after $24 \mathrm{~h}$ of culture with addition of PHA $(24 \mathrm{hr}+\mathrm{PHA})$. Results are the mean of three independent experiments using cell samples from three different donors. ${ }^{\star} P<0.01$ when compared with control.

cells and tumour cells studied. In immortalized T- and B-cell lines, sst $_{2 \mathrm{~A}}$ and $\mathrm{sst}_{3}$ were also both present. However, these cell lines contained approximately 10-20 times more hprt mRNA per cell than naïve
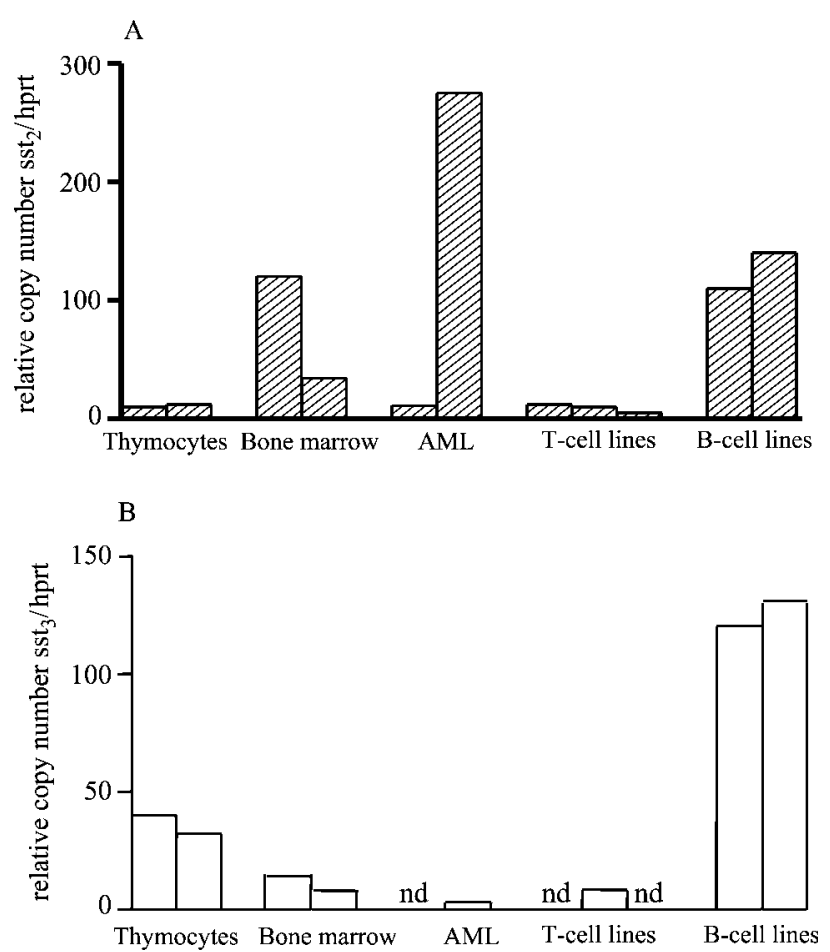

Figure 5 Expression of $\mathrm{sst}_{2 \mathrm{~A}}$ and $\mathrm{sst}_{3} \mathrm{mRNA}$ in human immune cells and cell lines. $s_{2 A}$ and $s_{2} t_{3}$ levels were corrected for the amount of hprt detected in each sample and are given in arbitrary units. (A) Expression of $s_{2 \mathrm{~A}}$ in cell suspensions from normal human thymocytes $(n=2)$, normal human bone marrow $(n=2)$, acute myeloid leukaemia (AML) cells $(n=2)$, established T-lymphoid cell lines Jurkat, HPB-ALL and Peer, and two EBV-transformed B-cell lines. (B) Expression of sst $_{3}$ mRNA was evaluated in the same preparations. $\mathrm{nd}=$ not detected.
PBMCs. Therefore the absolute numbers of $\mathrm{sst}_{2 \mathrm{~A}}$ and sst $_{3}$ mRNA copies obtained per million cells were much higher than in PBMCs. In established T-cell lines the amount of $\mathrm{sst}_{2 \mathrm{~A}}$ was at least 10 times higher than in naïve PBMCs (10 000-60000 copies obtained per million cells), while $\mathrm{sst}_{3}$ expression was comparable with PBMCs. In transformed B-cell lines both sst $_{2 \mathrm{~A}}$ and $\mathrm{sst}_{3}$ levels were much higher than in naïve PBMCs (500 000-800000 copies obtained per million cells, i.e. more than 500 and 35 times higher for $\mathrm{sst}_{2 \mathrm{~A}}$ and $\mathrm{sst}_{3}$ respectively).

Finally, we evaluated the expression of CST mRNA in T- and B-lymphocytes by Q-PCR. T-lymphocytes expressed CST, and CST mRNA levels were downregulated when the cells were incubated with PHA (Fig. 6A). CST expression in B-lymphocytes could only be detected in two out of three donors and in these two donors we found an upregulation after $24 \mathrm{~h}$ of culture. However, when the cells were cultured for $24 \mathrm{~h}$ with addition of PHA, CST levels returned to basal levels (Fig. 6B).

\section{Fluo-SS ligand binding to monocytes}

To confirm that, besides sst mRNA, the protein could also be detected as ligand-binding sites, we performed FACS analysis on cell populations of naïve PBMCs, PHA-activated non-adherent PBMCs (i.e. enriched for T- and B-lymphocytes) and on LPS-activated Percoll gradient-isolated monocytes (purity 70-90\%). The purity of monocytes was determined by FACS analysis, using CD14, CD68, CD71, CD26, CD1a, CD80, CD86 and HLADR antibodies (data not shown). The cells of the purified monocyte fraction were positive for CD14, CD26, CD71, CD86 and HLA-DR (70-90\%), in agreement with the CD-marker expression pattern of monocytes (35). Using the fluorescent SS14 analogue we were able to detect sst only in the activated monocyte-enriched cell population, but not in the naïve PBMC fraction or in the activated non-adherent PBMC fraction. The signal was specific for SS because it was displaced by addition of excess unlabelled SS14 analogue (Fig. 7).

\section{Discussion}

In the present study we have determined for the first time unequivocally that only $\mathrm{sst}_{3}$ is expressed at significant levels in human PBMCs, resembling the in vivo situation as closely as possible. This expression is found in B-lymphocytes, as well as in T-lymphocytes, but not in monocytes. Expression of $\mathrm{sst}_{3}$ mRNA in B-lymphocytes was significantly lower compared with the expression of this sst in T-lymphocytes. Freshly isolated monocytes derived from peripheral blood do not express any of the five sst, but upon activation these cells were shown to express $\mathrm{sst}_{2 \mathrm{~A}} \mathrm{mRNA}$. Previously, 
A T- lymphocyles

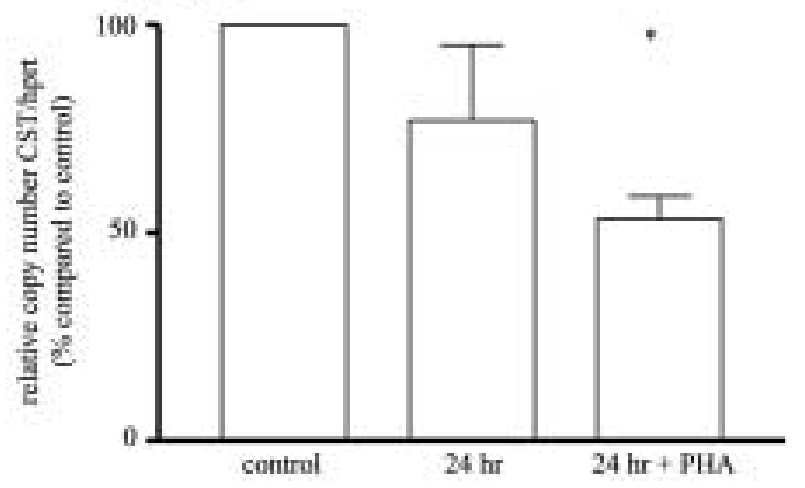

B H- bmphocgtes

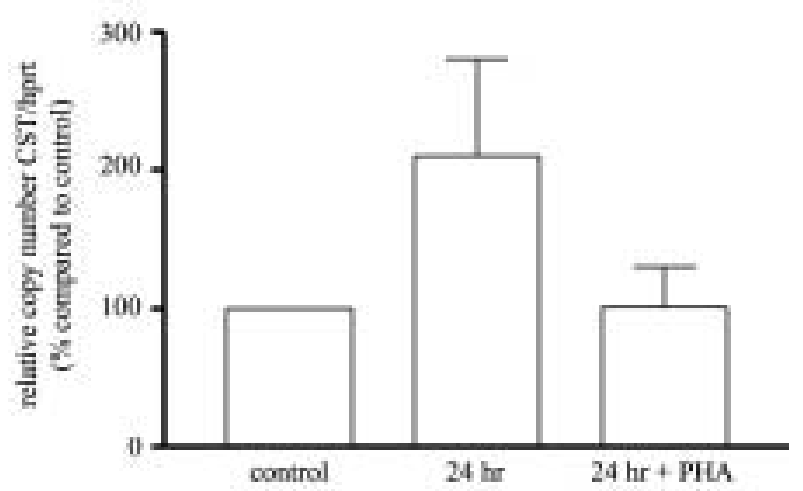

Figure 6 Expression of CST mRNA in human B- and T-lymphocytes. Expression of CST mRNA was determined in unstimulated cells (control), after $24 \mathrm{~h}$ of culture $(24 \mathrm{hr}$ ) and after $24 \mathrm{~h}$ of culture with addition of PHA (24 hr + PHA). (A) Expression of CST mRNA in T-lymphocytes (mean of three donors). ${ }^{*} P<0.001$ when compared with control cells. (B) Expression of CST mRNA in B-lymphocytes (mean of two donors). Bars represent the percentage of upregulation when compared with control.

we demonstrated that monocytes, after a Ficoll and Percoll density-gradient centrifugation, express a very low amount of sst $_{2 \mathrm{~A}}$ mRNA (36). This suggests that already minimal activation, caused by the Percoll density-gradient centrifugation step, of the cells results in upregulation of $\mathrm{sst}_{2 \mathrm{~A}}$ mRNA. Stimulation of T- and Blymphocytes with non-specific mitogens did not alter the expression pattern of receptor subtypes. SS mRNA was undetected in all cell populations studied, whereas we detected CST mRNA in lymphocytes. In a previous study we demonstrated expression of the SS-like peptide CST in monocytes and its functionally derived cells, i.e. macrophages and dendritic cells (36). Since the sensitivity of our assay was set at detection of expression in approximately $10 \%$ of the cell population, it is not known whether all T- and B-lymphocytes express $\mathrm{sst}_{3}$, or whether sst $_{3}$ expression is restricted to a subset of the T- and B-lymphocytes. Separation of T-lymphocytes into the major subpopulations of $\mathrm{CD} 4^{+} \mathrm{T}$-helper cells and $\mathrm{CD}^{+}$cytotoxic T-cells showed $\mathrm{sst}_{3}$ mRNA to be present in both. Using Fluo-SS derivative in FACS analysis we were not able to detect sst on the T- or B-lymphocyte populations. This could suggest that the expression of $\mathrm{sst}_{3}$ in these cells is very low or restricted to a very minor subset of the lymphocytes or, alternatively, that the Fluo-SS derivative has altered specificity for sst $_{3}$. Moreover, previous studies have demonstrated that in the cerebellum high levels of sst $_{3}$ receptors could be detected, while radioligand-binding studies failed to detect $\mathrm{sst}_{3}$-binding sites in this region (37, 38). Recent studies have shown that sst can form either homo- or heterodimers with other sst or other G-protein coupled receptors $(39,40)$. Heterodimerization of sst $_{3}$ with sst $_{2}$ resulted in a 100-fold lower affinity for $\mathrm{sst}_{3}$-selective agonists, compared with cells selectively expressing $\mathrm{sst}_{3}$ (39). However, heterodimerization of $\mathrm{sst}_{3}$ with other sst can be ruled out in lymphocytes, as no other sst are expressed. Therefore, heterodimerization with other members of the G-protein coupled receptor family might provide a potential explanation for the difficulty in detecting $\mathbf{s s t}_{3}$-binding sites in our studies. Further studies will have to elucidate this issue.

A number of studies have shown functional effects of SS on human lymphocytes $(6,20,41,42)$, providing evidence for the presence of functional sst on these cells. Corroborating our data, sst $_{3}$ was recently shown to be present in human enriched lymphocyte fractions, which also contained functional SS-binding sites (43). Our data obtained with Q-PCR on PBMC samples reveal that the number of $\mathrm{sst}_{3} \mathrm{cDNA}$ copies obtained per million cells is approximately 15000 or less. Assuming that the combined efficiency of RNA isolation and cDNA synthesis is in the order of $10 \%$, this suggests that only a subpopulation of the T-lymphocytes (which comprise more than $50 \%$ of the PBMC population) express sst $_{3}$.

Freshly isolated monocytes do not express sst $_{2 \mathrm{~A}}$ or $\mathrm{sst}_{3}$ at detected levels, but can be induced to express $\mathrm{sst}_{2 \mathrm{~A}}$ receptor mRNA. The presence of sst on these activated monocytes was confirmed using Fluo-SS and FACS analysis. Any of the non-specific stimuli we applied was sufficient to trigger this induction. Expression of $\mathrm{sst}_{2 \mathrm{~A}}$ was in some samples detectable as early as $1 \mathrm{~h}$ after stimulation. These observations suggest that $\mathrm{sst}_{2 \mathrm{~A}}$ upregulation is a very early event in activation of monocytes. By Q-PCR we showed that the level of $\mathrm{sst}_{2 \mathrm{~A}}$ induction varies among different donors, but that it is very substantial in all cases.

Translating our results with naïve and in vitro-activated immune cells from the peripheral circulation to the situation for immune cells present in lymphatic tissues, it seems very likely that the receptor-binding sites found with radiolabelled SS (analogues) are present on immune cells from the monocytic lineage. Whether the lymphocytes after migration into the tissues also express sufficient amounts of sst to be visualized in autoradiography is uncertain, since T-lymphocyte-rich regions in lymphoid tissues were reported to be sst negative and 

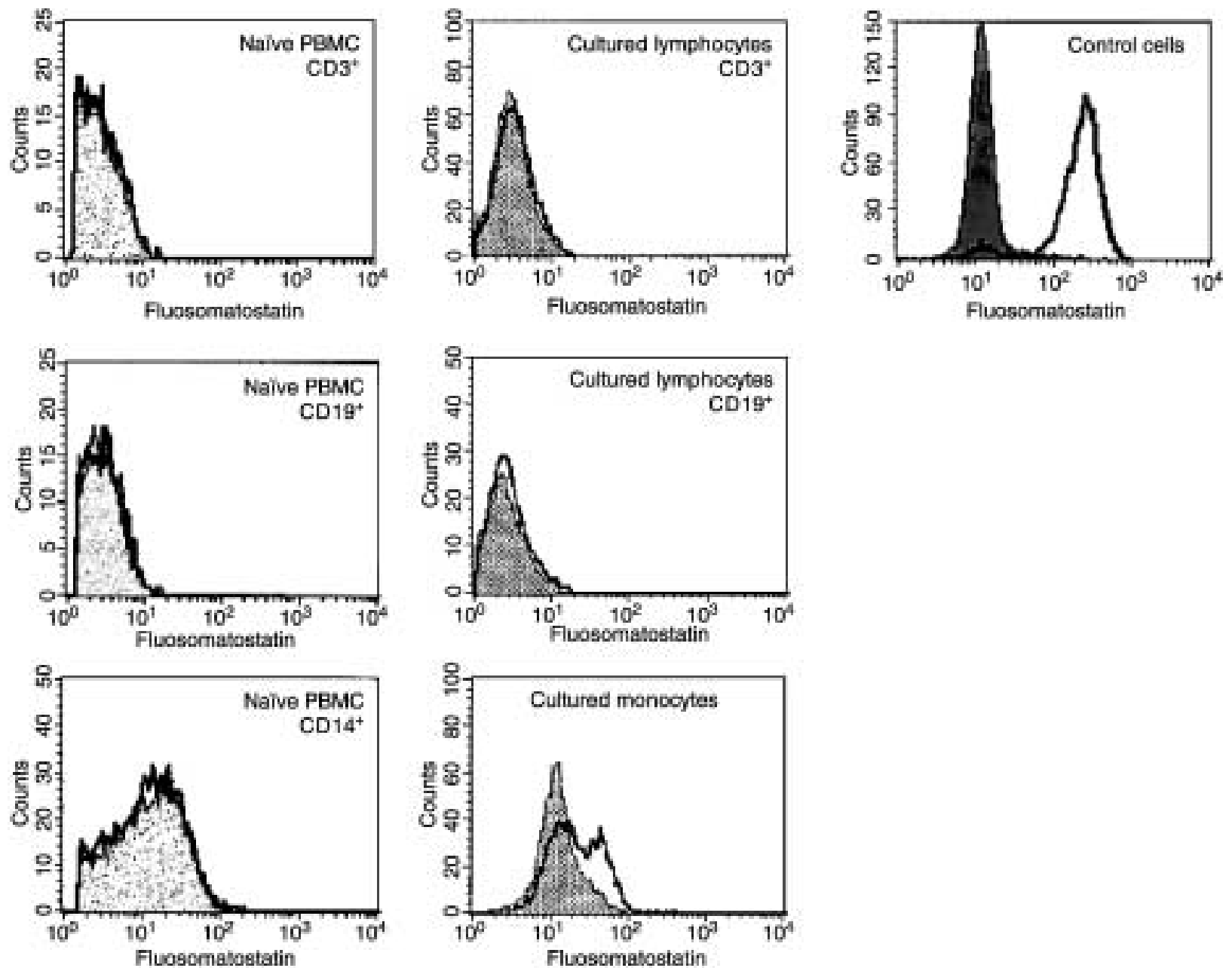

Figure 7 FACS analysis of Fluo-SS binding to T- or B-lymphocytes or to monocytes. Naïve PBMCs or an enriched lymphocyte population cultured for $24 \mathrm{~h}$ in the presence of PHA were labelled with Fluo-SS and PE-conjugated CD3 or CD19 antibodies to analyse binding of SS to T- and B-lymphocytes respectively. Monocytes were analysed by labelling the naïve PBMCs with Fluo-SS and PEconjugated CD14 antibody and by labelling an enriched monocyte population cultured for $24 \mathrm{~h}$ in the presence of LPS with Fluo-SS. The grey areas represent the fluorescent signal remaining after displacement of Fluo-SS by unlabelled SS, the solid line shows the amount of fluorescence after labelling with Fluo-SS. These data are examples of one of the experiments carried out and represent the data found in three independent healthy donors.

germinal centres of secondary lymphatic follicles rich in B-lymphocytes were shown to be receptor positive by autoradiography $(10,44)$. Our recent studies using a sst $_{2 \mathrm{~A}}$-specific antibody for immunohistochemistry confirmed the presence of the $\mathrm{sst}_{2 \mathrm{~A}}$ receptor on cells of the monocytic lineage and the absence of this receptor from T-lymphocytes in human rheumatoid synovium (13) and sarcoid granuloma tissue biopsies (12). However, we cannot rule out the possibility that one or more of the receptor subtypes is upregulated by other, more specific stimuli than the ones we applied. Furthermore, cells other than lymphocytes or monocytes/ macrophages in lymphoid tissues are likely to express SS and sst as well, such as has been shown in endothelial cells in inflammatory lesions (13) and in thymic epithelial cells from normal human thymus (31).
Knowing these results, we may now understand much better the data described so far in the literature. Whether or not sst were detected in PBMCs presumably depended on the extent to which monocytes were activated during isolation of the PBMCs $(17-19)$. Moreover, our results show that sst mRNA expression in established cell lines may not necessarily be representative for human immune cells in vivo. Most of the lymphoid cell lines studied by Tsutsumi et al. (19) expressed mRNA for $\mathrm{sst}_{2-5}$, with sst ${ }_{2}$ being the major subtype. Our own studies of a panel of lymphoid cell lines revealed only $\mathrm{sst}_{2 \mathrm{~A}}$ and $\mathrm{sst}_{3}$ or no SS receptor expression at all $(26,45)$. The incongruity possibly can be explained by differences in assay sensitivity. Nevertheless, it is evident that many lymphoid cell lines express sst $_{2 \mathrm{~A}}$ as the major subtype, which is 
certainly at variance with lymphoid cells in the circulation. Our comparison of human PBMCs and human lymphoid cell lines also revealed that in immortalized cell lines the expression level of $\mathrm{sst}_{2 \mathrm{~A}}$ is similar to or much higher than in activated PBMCs. Since also the amount of hprt RNA per cell was much higher in the cell lines than in PBMCs, presumably due to the enhanced proliferative capacity of the immortalized cells, the absolute numbers of $\mathrm{sst}_{2 \mathrm{~A}}$ and $\mathrm{sst}_{3}$ mRNA copies per cell are 10- to 800-fold higher in the immortalized cell lines.

Results reported in studies concerning the function of SS and its receptors in immune cells are not conclusive as to which sst mediate the different effects. On the other hand, expression of $\mathrm{sst}_{2}$ receptors has been found to be of major interest in the treatment of patients with growth hormone-secreting pituitary adenomas, carcinoids and other gastroenteropancreatic tumours (46-48). Treatment of these patients with SS analogues has demonstrated an improvement of clinical symptoms due to the inhibition of the secretion of hormones or bioactive peptides by the tumour cells (48). In addition, reduction of tumour mass has been observed in selected cases. Apart from their important role in therapy, sst can also play a role in diagnosis of disease. Radiolabelled SS analogues are used for visualization of neuroendocrine tumours (49), but also, diseases involving cells of the human immune system, like Hodgkin's and non-Hodgkin's lymphomas and sarcoidosis, can be visualized by a gamma camera after binding of radiolabelled SS analogues to $\mathrm{sst}_{2}$ receptors present in affected tissues in these diseases $(16,50,51)$. These studies have thus shown that sst can play a major role in diagnosis and therapy of various diseases.

In vitro culturing of human PBMCs has demonstrated effects of SS or its analogues on numerous (immune) functions of these cells. However, several conflicting results regarding effects of SS (or its analogue octreotide) on proliferation, differentiation or cytokine production have been reported (discussed below), which possibly can be attributed to different experimental designs but do not clarify the function of SS in the immune system.

$\mathrm{sst}_{2 \mathrm{~A}}$ receptors are usually associated with inhibition of hormone secretion $(52,53)$. Also, for LPS-activated human monocytes, it has been shown that SS inhibits the secretion of pro-inflammatory cytokines (54), although another study reported stimulation of secretion (55). Notwithstanding these conflicting accounts, the biological significance of the early induction of $\mathrm{sst}_{2 \mathrm{~A}}$ during activation of monocytes might be that through this receptor the inflammatory response could be modulated (decreased) immediately it is invoked. The presence of SS-binding sites in rheumatoid arthritis or in granulomatous diseases $(15,16,25)$ and the effects of SS in arthritis (56) also suggest that SS may act in inflammation. Consistent with the suggestion that $\mathrm{sst}_{2 \mathrm{~A}}$ could mediate these effects are our recent studies demonstrating the presence of $\mathrm{sst}_{2 \mathrm{~A}}$ by immunohistochemistry in cells of the monocytic lineage in human rheumatoid synovium and sarcoid granulomas $(12,13)$.

The identification of SS-binding sites in haematological malignancies and the ability of SS (or octreotide) to inhibit proliferation of these malignant cells in vitro (18, 57 ) hints at a role for SS in the regulation of proliferation and/or differentiation during haematopoiesis. The presence of $\mathrm{sst}_{2 \mathrm{~A}}$ in normal human bone marrow cells, where differentiation and proliferation take place, as well as in tumour cells from haematological origin might suggests that $\mathrm{sst}_{2 \mathrm{~A}}$ is involved in regulating the balance between proliferation and differentiation. Moreover, recent studies have shown that SS, acting via $\mathrm{sst}_{2}$, induces migration of human haematopoietic progenitor cells (58). These findings suggest that $\mathrm{sst}_{2}$ on human immune cells may play a role in homing of the cells during differentiation or in immune reactions by chemotaxis.

In human PBMCs, inhibition of proliferation of mitogen-activated lymphocytes has been reported $(20,41$, 42 ), although contrasting results have also been obtained with enriched lymphocyte fractions (43) and with a lymphoid cell line (22). In the latter studies proliferation could be stimulated by SS. Because lymphocytes selectively express $\mathrm{sst}_{3}$ mRNA, we suggest that this receptor subtype mediates the responses observed in this cell type. Interestingly, $\mathrm{sst}_{3}$ has been shown to be involved in SS-induced apoptosis, resulting in growth inhibition of the cell population (59). Our finding that $\mathrm{sst}_{3}$ is the main subtype expressed in mature lymphocytes and, moreover, the upregulation of $\mathrm{sst}_{3}$ mRNA in T-lymphocytes during culture and by activation with PHA, suggests that this receptor subtype may have an important function in these cells. Mature B- and T-lymphocytes in the circulation are resting cells that start proliferation after activation. It is therefore conceivable that in mature B- and T-lymphocytes $\mathrm{sst}_{3}$ may have an important function in regulating the balance between proliferation and apoptosis after activation. However, with respect to the possible role of $\mathrm{sst}_{3}$ in mature B-lymphocytes we could only detect $\mathrm{sst}_{3}$ mRNA by RT-PCR, and not by Q-PCR. This suggests that $\mathrm{sst}_{3}$ mRNA expression in B-lymphocytes is very low and therefore it may be hypothesized that $\mathrm{sst}_{3}$ in B-lymphocytes plays a less important regulatory role, when compared with T-lymphocytes, in which we found clear regulation of $\mathrm{sst}_{3}$ mRNA expression.

Equally important for the understanding of the function of SS and its receptors in lymphoid tissues is knowledge of which cells produce the agonistic peptide SS. We demonstrated that PBMCs do not synthesize SS mRNA, not even after activation. We therefore assume that SS is synthesized in other cells in the lymphoid tissues, e.g. in thymic epithelial cells (31) or in nerve endings, or perhaps in endothelial cells. Another possibility is that lymphocytes or monocyte-derived cells do express SS mRNA after more specific stimulation in vivo, conceivably after 
migration from the periphery into lymphoid tissues or to sites of inflammation. On the other hand, the detection of CST mRNA in various tissues and cells of the human immune system (27) and the detection of CST mRNA in the present study in T- and B- lymphocytes may suggest that CST, rather than SS, may play a regulatory role acting via the sst in these immune cells. However, in monocytes, macrophages and dendritic cells, CST mRNA was upregulated upon activation with LPS (27), whereas in B- and T-lymphocytes we found in general a downregulation of the CST mRNA expression upon activation. The significance of this downregulation in T- and B-lymphocytes as well as the functional significance of CST in these cells remains to be determined. We hypothesized that the downregulation of endogenous CST expression may be a direct feedback mechanism following the upregulation of $\mathrm{sst}_{3}$, in order to regulate responsiveness to the peptide. This suggests that CST and sst $_{3}$ may interact in regulation of the number of T-cells. Although we have now extensively demonstrated the expression of different sst and their ligands in cells of the human immune system in vitro, the functional significance of SS and its receptors in the human immune system in vivo remains largely unknown. As discussed above, previous studies have shown different (conflicting) results. Further studies will have to demonstrate the functional significance of SS or SS-like peptides and their receptors in vivo and the potential implications for treatment of immunological diseases.

Summarizing, we have shown for the first time that human B- and T-lymphocytes in the peripheral blood selectively express $\mathrm{sst}_{3}$, whereas circulating monocytes do not express sst. Expression of $\mathrm{sst}_{3}$ mRNA can be upregulated by activation in T-lymphocytes, while sst $_{3}$ expression levels in B-lymphocytes are probably very low, suggesting a less important role of these receptors in B-lymphocytes, when compared with T-lymphocytes. Upon stimulation with non-specific mitogens the monocytes, but not the lymphocytes, are induced to express $\mathrm{sst}_{2 \mathrm{~A}}$ receptors. No expression of SS mRNA was detected, not even after stimulation. In line with the expression of CST mRNA in monocytes, macrophages and dendritic cells, CST mRNA is expressed in T- and B-lymphocytes as well. The differential and cell-type-specific regulation of the expression of $\mathrm{sst}_{2 \mathrm{~A}}$ and $\mathrm{sst}_{3}$ receptors in human PBMC, in combination with data on functional studies of SS on immune cells, suggests that the function of SS, or more presumably CST, and its receptors in the human immune system may be found in regulating cytokine secretion in inflammatory responses and in regulating the balance of proliferation and apoptosis of (activated) lymphocytes in immune responses.

\section{Acknowledgement}

This research project was supported by grant 903-43092 from the Dutch Organization for Scientific
Research (Nederlandse organisatie voor Wetenschappelijk Onderzoek).

\section{References}

1 Brazeau P, Vale W, Burgus R, Ling N, Butcher M, Rivier J et al. Hypothalamic polypeptide that inhibits the secretion of immunoreactive pituitary growth hormone. Science $1973 \mathbf{1 7 9} 77-79$.

2 Brazeau P. Somatostatin: a peptide with unexpected physiologic activities. American Journal of Medicine $1986 \mathbf{8 1} 8-13$.

3 Pearse AG, Polak JM \& Bloom SR. The newer gut hormones. Cellular sources, physiology, pathology, and clinical aspects. Gastroenterology $1977 \mathbf{7 2} 746-761$.

4 Chesselet MF, Soghomonian JJ \& Salin P. Anatomical localization and regulation of somatostatin gene expression in the basal ganglia and its clinical implications. CIBA Foundation Symposia $199519051-59$.

5 van Hagen PM, Krenning EP, Kwekkeboom DJ, Reubi JC, AnkerLugtenburg PJ, Lowenberg B et al. Somatostatin and the immune and haematopoietic system; a review. European Journal of Clinical Investigation $1994 \mathbf{2 4} 91-99$.

6 Krantic S. Peptides as regulators of the immune system: emphasis on somatostatin. Peptides 200021 1941-1964.

7 Schonbrunn A \& Tashjian H Jr. Characterization of functional receptors for somatostatin in rat pituitary cells in culture. Journal of Biological Chemistry 1978253 6473-6483.

8 Patel YC. Somatostatin and its receptor family. Frontiers in Neuroendocrinology 199920 157-198.

9 Reubi JC, Waser B, van Hagen M, Lamberts SW, Krenning EP, Gebbers JO et al. In vitro and in vivo detection of somatostatin receptors in human malignant lymphomas. International Journal of Cancer $1992 \mathbf{5 0} 895-900$.

10 Reubi JC, Horisberger U, Kappeler A \& Laissue JA. Localization of receptors for vasoactive intestinal peptide, somatostatin, and substance $\mathrm{P}$ in distinct compartments of human lymphoid organs. Blood 199892 191-197.

11 Reubi JC, Waser B, Horisberger U, Krenning E, Lamberts SW, Gebbers JO et al. In vitro autoradiographic and in vivo scintigraphic localization of somatostatin receptors in human lymphatic tissue. Blood $1993 \mathbf{8 2} 2143-2151$.

12 ten Bokum AM, Hofland LJ, de Jong G, Bouma J, Melief MJ, Kwekkeboom DJ et al. Immunohistochemical localization of somatostatin receptor sst $2 \mathrm{~A}$ in sarcoid granulomas. European Journal of Clinical Investigation 199929 630-636.

13 ten Bokum AM, Melief MJ, Schonbrunn A, van der Ham F, Lindeman J, Hofland LJ et al. Immunohistochemical localization of somatostatin receptor sst $2 \mathrm{~A}$ in human rheumatoid synovium. Journal of Rheumatology $1999 \mathbf{2 6} 532-535$.

14 Vanhagen PM, Krenning EP, Reubi JC, Mulder AH, Bakker WH, Oei HY et al. Somatostatin analogue scintigraphy of malignant lymphomas. British Journal of Haematology 199383 75-79.

15 Vanhagen PM, Markusse HM, Lamberts SW, Kwekkeboom DJ, Reubi JC \& Krenning EP. Somatostatin receptor imaging. The presence of somatostatin receptors in rheumatoid arthritis. Arthritis and Rheumatism $1994371521-1527$.

16 Vanhagen PM, Krenning EP, Reubi JC, Kwekkeboom DJ, Bakker WH, Mulder AH et al. Somatostatin analogue scintigraphy in granulomatous diseases. European Journal of Nuclear Medicine 199421 497-502.

17 Bhathena SJ, Louie J, Schechter GP, Redman RS, Wahl L \& Recant L. Identification of human mononuclear leukocytes bearing receptors for somatostatin and glucagon. Diabetes 198130 $127-131$.

18 Hiruma K, Koike T, Nakamura H, Sumida T, Maeda T, Tomioka H et al. Somatostatin receptors on human lymphocytes and leukaemia cells. Immunology 199071 480-485.

19 Tsutsumi A, Takano H, Ichikawa K, Kobayashi S \& Koike T. Expression of somatostatin receptor subtype 2 mRNA in human lymphoid cells. Cellular Immunology 1997181 44-49. 
20 Atiya A, Malik M, Une S, Shevlin L, Coy D \& Brunicardi FC. Immunomodulatory activities of the somatostatin receptor subtype analogues on human peripheral blood lymphocytes. Transplantation Proceedings 1997292151.

21 Sreedharan SP, Kodama KT, Peterson KE \& Goetzl EJ. Distinct subsets of somatostatin receptors on cultured human lymphocytes. Journal of Biological Chemistry $1989264949-952$.

22 Cardoso A, el Ghamrawy C, Gautron JP, Horvat B, Gautier N, Enjalbert A et al. Somatostatin increases mitogen-induced IL-2 secretion and proliferation of human Jurkat $\mathrm{T}$ cells via sst3 receptor isotype. Journal of Cellular Biochemistry 199868 62-73.

23 Nio DA, Moylan RN \& Roche JK. Modulation of T lymphocyte function by neuropeptides. Evidence for their role as local immunoregulatory elements. Journal of Immunology $1993 \mathbf{1 5 0}$ 5281-5288.

24 Tang SC, Braunsteiner H \& Wiedermann CJ. Regulation of human T lymphoblast growth by sensory neuropeptides: augmentation of cholecystokinin-induced inhibition of Molt-4 proliferation by somatostatin and vasoactive intestinal peptide in vitro. Immunology Letters 199234 237-242.

25 ten Bokum AM, Lichtenauer-Kaligis EG, Melief MJ, van Koetsveld PM, Bruns C, van Hagen PM et al. Somatostatin receptor subtype expression in cells of the rat immune system during adjuvant arthritis. Journal of Endocrinology 1999161 167-175.

26 Lichtenauer-Kaligis EG, van Hagen PM, Lamberts SW \& Hofland LJ. Somatostatin receptor subtypes in human immune cells. European Journal of Endocrinology 2000143 (Suppl 1) S21-S25.

27 Dalm VA, van Hagen PM, van Koetsveld PM, Langerak AW, van der Lely A, Lamberts SW et al. Cortistatin rather than somatostatin as a potential endogenous ligand for somatostatin receptors in the human immune system. Journal of Clinical Endocrinology and Metabolism 200388 270-276.

28 de Lecea L, Criado JR, Prospero-Garcia O, Gautvik KM, Schweitzer P, Danielson PE et al. A cortical neuropeptide with neuronal depressant and sleep-modulating properties. Nature $1996 \mathbf{3 8 1}$ 242-245.

29 Fukusumi S, Kitada C, Takekawa S, Kizawa H, Sakamoto J, Miyamoto $\mathrm{M}$ et al. Identification and characterization of a novel human cortistatin-like peptide. Biochemical and Biophysical Research Communications 1997232 157-163.

30 Kabel PJ, de Haan-Meulman M, Voorbij HA, Kleingeld M, Knol EF \& Drexhage HA. Accessory cells with a morphology and marker pattern of dendritic cells can be obtained from elutriator-purified blood monocyte fractions. An enhancing effect of metrizamide in this differentiation. Immunobiology 1989179 395-441.

31 Ferone D, van Hagen PM, van Koetsveld PM, Zuijderwijk J, Mooy DM, Lichtenauer-Kaligis EG et al. In vitro characterization of somatostatin receptors in the human thymus and effects of somatostatin and octreotide on cultured thymic epithelial cells. Endocrinology $1999140373-380$.

32 Holland PM, Abrahamson RD, Watson R \& Gelfand DH. Detection of specific polymerase chain reaction product by utilizing the $5^{\prime}-3^{\prime}$ exonuclease activity of Thermus aquaticus DNA polymerase. PNAS $1991887276-7280$.

33 Heid CA, Stevens J, Livak KJ \& Williams PM. Real time quantitative PCR. Genome Research 1996 6 986-994.

34 Livak KJ, Flood SJ, Marmaro J, Giusti W \& Deetz K. Oligonucleotides with fluorescent dyes at opposite ends provide a quenched probe system useful for detecting PCR product and nucleic acid hybridization. PCR Methods and Applications 19954 357-362.

35 Herbert L. CD antigens, based on CD designations made at the 7 th Workshop on Human Leucocyte Differentiation Antigens. In Immunobiology: the Immune System in Health and Disease, edn 5, appendix II. Eds CA Janeway, P Travers, M Walport \& M Shlomchik. New York: Garland Publishing, 2001.

36 Dalm VA, van Hagen PM, van Koetsveld PM, Achilefu S, Houtsmuller AB, Pols DH et al. Expression of somatostatin, cortistatin and somatostatin receptors in human monocytes, macrophages and dendritic cells. American Journal of Physiology. Endocrinology and Metabolism 2003285 E344-E353.
37 Handel M, Schulz S, Stanarius A, Schreff M, Erdtmann-Vourliotis $\mathrm{M}$, Schmidt $\mathrm{H}$ et al. Selective targeting of somatostatin receptor 3 to neuronal cilia. Neuroscience 199989 909-926.

38 Perez J, Rigo M, Kaupmann K, Bruns C, Yasuda K, Bell GI et al. Localization of somatostatin (SRIF) SSTR-1, SSTR-2 and SSTR-3 receptor mRNA in rat brain by in situ hybridization. NaunynSchmiedeberg's Archives of Pharmacology 1994349 145-160.

39 Pfeiffer M, Koch T, Schroder H, Klutzny M, Kirscht S, Kreienkamp HJ et al. Homo- and heterodimerization of somatostatin receptor subtypes. Inactivation of sst(3) receptor function by heterodimerization with sst(2A). Journal of Biological Chemistry 2001276 14027-14036.

40 Pfeiffer M, Koch T, Schroder H, Laugsch M, Hollt V \& Schulz S. Heterodimerization of somatostatin and opioid receptors crossmodulates phosphorylation, internalization and desensitization. Journal of Biological Chemistry 200214 19762-19772.

41 Fais S, Annibale B, Boirivant M, Santoro A, Pallone F \& Delle Fave G. Effects of somatostatin on human intestinal lamina propria lymphocytes. Modulation of lymphocyte activation. Journal of Neuroimmunology 199131 211-219.

42 Malec P, Zeman K, Markiewicz K, Tchorzewski H, Nowak Z \& Baj Z. Short-term somatostatin infusion affects T lymphocyte responsiveness in humans. Immunopharmacology 198917 45-49.

43 Ghamrawy CE, Rabourdin-Combe C \& Krantic S. sst5 somatostatin receptor mRNA induction by mitogenic activation of human T-lymphocytes. Peptides 199920 305-311.

44 Reubi JC, Horisberger U, Waser B, Gebbers JO \& Laissue J. Preferential location of somatostatin receptors in germinal centers of human gut lymphoid tissue. Gastroenterology $1992 \quad 103$ $1207-1214$.

45 van Hagen PM, Hofland LJ, ten Bokum AM, Lichtenauer-Kaligis EG, Kwekkeboom DJ, Ferone D et al. Neuropeptides and their receptors in the immune system. Annals of Medicine 199931 (Suppl 2) 15-22.

46 Scarpignato C \& Pelosini I. Somatostatin analogs for cancer treatment and diagnosis: an overview. Chemotherapy 200147 1-29.

47 Lamberts SW, van der Lely AJ, de Herder WW \& Hofland LJ. Octreotide. New England Journal of Medicine 1996334 246-254.

48 Lamberts SW, de Herder WW, van Koetsveld PM, Koper JW, van der Lely AJ, Visser-Wisselaar HA et al. Somatostatin receptors: clinical implications for endocrinology and oncology. CIBA Foundation Symposia $1995190222-236$.

49 Breeman WA, de Jong M, Kwekkeboom DJ, Valkema R, Bakker WH, Kooij PP et al. Somatostatin receptor-mediated imaging and therapy: basic science, current knowledge, limitations and future perspectives. European Journal of Nuclear Medicine 200128 1421-1429.

50 Lugtenburg PJ, Krenning EP, Valkema R, Oei HY, Lamberts SW, Eijkemans MJ et al. Somatostatin receptor scintigraphy useful in stage I-II Hodgkin's disease: more extended disease identified. British Journal of Haematology 2001112 936-944.

51 Lugtenburg PJ, Lowenberg B, Valkema R, Oei HY, Lamberts SW, Eijkemans MJ et al. Somatostatin receptor scintigraphy in the initial staging of low-grade non-Hodgkin's lymphomas. Journal of Nuclear Medicine $200142222-229$.

52 Moldovan S, Atiya A, Adrian TE, Kleinman RM, Lloyd K, Olthoff K et al. Somatostatin inhibits B-cell secretion via a subtype-2 somatostatin receptor in the isolated perfused human pancreas. Journal of Surgical Research 199559 85-90.

53 Shimon I, Taylor JE, Dong JZ, Bitonte RA, Kim S, Morgan B et al. Somatostatin receptor subtype specificity in human fetal pituitary cultures. Differential role of SSTR2 and SSTR5 for growth hormone, thyroid-stimulating hormone, and prolactin regulation. Journal of Clinical Investigation 199799 789-798.

54 Peluso G, Petillo O, Melone MA, Mazzarella G, Ranieri M \& Tajana GF. Modulation of cytokine production in activated human monocytes by somatostatin. Neuropeptides $199630443-451$.

55 Komorowski J \& Stepien H. Somatostatin (SRIF) stimulates the release of interleukin-6 (IL-6) from human peripheral blood monocytes (PBM) in vitro. Neuropeptides 199529 77-81. 
56 Sakane T \& Suzuki N. The role of somatostatin in the pathophysiology of rheumatoid arthritis. Clinical and Experimental Rheumatology $199816745-749$.

57 Santini V, Lamberts SW, Krenning EP, Backx B \& Lowenberg B. Somatostatin and its cyclic octapeptide analog SMS 201-995 as inhibitors of proliferation of human acute lymhoblastic and acute myeloid leukemia. Leukemia Research 199519 707-712.

58 Oomen SP, van Hennik PB, Antonissen C, Lichtenauer-Kaligis EG, Hofland LJ, Lamberts SW et al. Somatostatin is a selective chemoattractant for primitive $(\mathrm{CD} 34(+))$ hematopoietic progenitor cells. Experimental Hematology $200230116-125$.

59 Sharma K, Patel YC \& Srikant CB. Subtype-selective induction of wild-type p53 and apoptosis, but not cell cycle arrest, by human somatostatin receptor 3. Molecular Endocrinology 199610 $1688-1696$.

60 Wulfsen I, Meyerhof W, Fehr S \& Richter D. Expression patterns of rat somatostatin receptor genes in pre- and postnatal brain and pituitary. Journal of Neurochemistry 199361 1549-1552.
61 Kubota A, Yamada Y, Kagimoto S, Shimatsu A, Imamura M, Tsuda $\mathrm{K}$ et al. Identification of somatostatin receptor subtypes and an implication for the efficacy of somatostatin analogue SMS 201-995 in treatment of human endocrine tumors. Journal of Clinical Investigation 199493 1321-1325.

62 Ejeskar K, Abel F, Sjoberg R, Backstrom J, Kogner P \& Martinsson T. Fine mapping of the human preprocortistatin gene (CORT) to neuroblastoma consensus deletion region $1 \mathrm{p} 36.3 \rightarrow \mathrm{p} 36.2$, but absence of mutations in primary tumors. Cytogenetics and Cell Genetics $2000 \mathbf{8 9} 62-66$.

Received 11 September 2003

Accepted 1 January 2004 